Pengaruh Media Massa dalam ... | 57

\title{
PENGARUH MEDIA MASSA DALAM KEBIJAKAN PENDIDIKAN
}

\author{
Toha Makhshun'1), Khalilurrahman'2)* \\ 1 Program Studi Pendidikan Agama Islam, \\ Universitas Islam Sultan Agung (UNISSULA) Semarang \\ 2 Program Studi Pendidikan Islam Anak Usia Dini, \\ Institut Agama Islam (IAI) Darussalam Martapura Kalimantan Selatan \\ *E-mail: khalilinsida@gmail.com
}

\begin{abstract}
The role of the mass media is very decisive in the delivery of information and a government policy. In line with the increasing level of communication technology development, the communication method rapid development as well. But all of that has the same accentuation that communicators convey messages and ideas to the publik. When detailed more concretely, the method of communication in the contemporary world which is the development of verbal and nonverbal communication covers many fields, including journalism, publik relations, advertising, exhibitions/ expositions, and publikations that will influence political culture. This paper will discuss more about the influence of mass media in education policy.
\end{abstract}

Keywords: Mass Media, Education Policy

\begin{abstract}
Abstrak
Peran media massa sangat menentukan dalam penyampaian informasi maupun suatu kebijakan pemerintah. Sejalan dengan tingkat perkembangan teknologi komunikasi yang kian pesat, maka metode komunikasi pun mengalami perkembangan yang pesat pula. Namun semua itu, mempunyai aksentuasi sama yakni komunikator menyampaikan pesan, ide dan gagasan kepada masyarakat. Bila dirinci secara lebih kongkrit, metode komunikasi dalam dunia kontemporer saat ini yang merupakan pengembangan dari komunikasi verbal dan nonverbal meliputi banyak bidang, antara lain jurnalistik, hubungan masyarakat, periklanan, pameran/ eksposisi, dan publikasi yang akan mempengaruhi budaya politik, sosial, maupun pendidikan. Tulisan ini akan membahas secara lebih lanjut tentang pengaruh media massa dalam kebijakan pendidikan.
\end{abstract}

Kata kunci: Media Massa, Kebijakan Pendidikan

\section{PENDAHULUAN}

Media massa adalah alat yang digunakan oleh manusia untuk menyampaikan pesan. Media massa menjadi penting karena memang memiliki kekuatan. Bukan sekedar mampu menyampaikan pesan kepada khalayak tetapi lebih karena media menjalankan fungsi mendidik, mempengaruhi, menginformaasikan dan menghibur. Adapun dalam UU no. 40/1999 disebutkan fungsi pers adalah pers nasional mempunyai fungsi sebagai media informasi, pendidikan, hiburan, dan media kontrol sosial. Kontrol sosial itu bisa berupa keikutsertaan rakyat dalam pemerintahan, 
58 | Toha Makhshun \& Khalilurrahman

pertanggungjawaban pemerintah pada rakyat (Masduki, 2004: 8). Media massa mempunyai peran yang sangat penting bagi kehidupan masyarakat, hal ini disebabkan masyarakat yang konsumtif akan suatu informasi yang dapat menunjang kehidupan mereka.

Peran media massa sangat menentukan dalam penyampaian informasi maupun suatu kebijakan pemerintah. Sejalan dengan tingkat perkembangan teknologi komunikasi yang kian pesat, maka metode komunikasi pun mengalami perkembangan yang pesat pula. Namun semua itu, mempunyai aksentuasi sama yakni komunikator menyampaikan pesan, ide dan gagasan, kepada masyarakat.

Bila dirinci secara lebih kongkrit, metode komunikasi dalam dunia kontemporer saat ini yang merupakan pengembangan dari komunikasi verbal dan nonverbal meliputi banyak bidang, antara lain jurnalistik, hubungan masyarakat, periklanan, pameran/eksposisi, dan publikasi yang akan mempengaruhi budaya politik. Dari sini kita akan mempelajari tentang media massa dan kebijakan pendidikan.

\section{PEMBAHASAN}

\section{Pengertian Media Massa}

Media massa (mass media) terdiri dari dua kata yaitu "media" dan "massa". Kata media dekat dengan pengertian "medium", "moderta" yang berarti tengah, sedang, penengah atau penghubung. Atau secara sosial-politis, "media" merupakan tempat, wahana, forum, atau lebih tepat lembaga penengah. Sedang "massa" adalah sesuatu yang tidak pribadi, sesuatu yang tidak personal, melainkan sesuatu yang berhubungan dengan orang banyak. Dengan demikian media massa adalah suatu lembaga netral yang berhubungan dengan orang banyak atau lembaga yang netral bagi semua kalangan atau masyarakat banyak (Niryawan, 2007: 54-56).

Dalam hal media massa kita mengenal istilah media cetak (pers) dan media penyiaran. Pengertian media cetak merupakan meliputi seluruh barang cetakan termasuk buku, namun dalam perkembangannya pengertian media cetak mengerucut menjadi surat kabar/ majalah/ tabloid (Niryawan, 2007: 62). Sedang pengertian media penyiaran merupakan meliputi radio dan televise (Niryawan, 2007: 64).

Untuk melengkapi pemahaman kita tentang media massa, kita harus tahu juga pengertian dari pers. Pengertian press (inggris) atau pers (belanda) berasal dari bahasa latin pressare yang berarti tekan atau cetak. Pers lalu diartikan sebagai media 
massa cetak (printing media) (Masduki, 2004: 7). Dalam konteks hubungan pers dan media, maka pers adalah bagian dari media secara luas. Media meliputi media cetak dan media elektronik, yang didalamnya terdapat pers cetak dan pers penyiaran (Niryawan, 2007:62). Sehingga menurut leksikon komunikasi, pers berarti:

1. Usaha percetakan atau penerbitan

2. Usaha pengumpulan dan penyiaran berita

3. Penyiaran berita melalui surat kabar, majalah, radio, dan televisi

4. Orang-orang yang bergerak dalam penyiaran berita (Djuroto, 2004:4).

Sebagaimana dikemukakan diatas, media massa pada hakikatnya adalah sekedar alat atau sarana dalam komunikasi massa yang bertugas membawa pesan yang harus disampaikan kepada massa. Namun pesan itu harus memiliki unsur-unsur tertentu agar dapat diterima dengan baik oleh massa. Unsur-unsur tersebut adalah:

1. Baru (faktor waktu). Hal inilah yang membedakan antara media massa dengan media sosial lainnya misalnya forum ilmiah, rapat politik atau ceramah agama. Pesan atau informasi dalam media massa merupakan pesan yang baru.

2. Menarik. Media massa akan memuat pesan atau informasi yang dianggap menarik oleh khalayak. Pengertian menarik ini memiliki arti yang luas. Menarik bisa dalam arti fisik, juga bisa berarti di dalam pesan tersebut terdapat aspek-aspek yang menjadi daya tarik khlayak. Misal: adanya konflik, kekerasan, human interest, sex dan sebagainya.

3. Penting. Misalnya: masalah kebijakan politik yang berdampak luas kepada masyarakat, bencana alam yang menyangkut keselamatan orang banyak, dan sebagainya (Niryawan, 2007).

Pada pasal 4 UU No. 40/1999 disebutkan hak-hak pers: kemerdekaan pers dijamin sebagai hak asasi warga Negara. Terhadap pers nasional tidak dikenakan sensor, pembredelan dan pelarangan penyiaran. Pers nasional mempunyai hak mencari, menyampaikan gagasan dan informasi kepada masyarakat. Adapun pasal 5 UU No. 40/1999 disebutkan kewajiban pers: memeritakan peristiwa dan opini dengan menghormati (1) norma-norma agama dan rasa kesusilaan masyarakat serta (2) asas praduga tak bersalah, pers wajib melayani hak jawab dan hak koreksi (Masduki, 2004:7). 
60 | Toha Makhshun \& Khalilurrahman

\section{Fungsi Media Massa}

Media massa telah memborong sejumlah fungsi yang dulu dilakukan oleh lembaga sosial lainnya. Beberapa fungsi media tersebut antara lain adalah:

1. Fungsi informasi. Media telah menjadi alat untuk mencari informasi bagi masyarakat. Dari media-lah berita lokal, nasional, dan manca Negara dapat diterima. Contoh: untuk mengetahui apakah jalan yang akan dilalui menuju tempat kerja macet atau tidak, untuk mengetahui keadaan sanak keluarga yang terkena musibah bencana alam, dan lain sebagainya.

2. Fungsi agenda. Melalui media, agenda manusia ditentukan. Orang akan mengerjakan apa hari ini banyak dipengaruhi oleh media. Contoh: banyak orang yang memiliki kebiasaan "sarapan" dengan membaca surat kabar atau menonton berita di televisi, banyak orang yang kini beralih sarapan pagi dengan mie instant daripada dengan nasi, anak-anak memilih komik berdasarkan film yang ditayangkan di televisi.

3. Fungsi penghubung orang. Tidak dapat dipungkiri bahwa media memiliki fungsi untuk menghubungkan manusia satu dengan manusia yang lain. Contoh: kasus bencana alam di aceh 2004, karena komunikasi antara aceh dan dunia luar terputus.

4. Pendidikan. Media massa sedikit banyak memberikan pesan tentang pendidikan. Contoh: bagaimana cara menjaga kesehatan, bagaimana menggunakan hak pilih, bagaimana mengatasi banjir dan sebagainya.

5. Fungsi membujuk. Bagaimana pun media juga memiliki kekuatan untuk membujuk atau merayu pendengar, penonton atau pembacanya. Contoh: kampanye agar masyarakat membayar pajak, atau agar menabung di bank dan sebagainya.

6. Fungsi menghibur. Fungsi ini sangat kental pada media penyiaran, dengan banyaknya acara sinetron, musik, lawak dan olah raga (Niryawan, 2007:60).

Adapun dalam UU no. 40/1999 disebutkan fungsi pers adalah pers nasional mempunyai funsi sebagai media informasi, pendidikan, hiburan, dan media control sosial. Control sosial itu bisa berupa keikutsertaan rakyat dalam pemerintahan, pertanggungjawaban pemerintah pada rakyat (Masduki, 2004:8). Jika lembaga pendidikan berperan menciptakan SDM yang berkualitas, maka menurut UU no. 40 tahun 1999, pers memiliki fungsi serupa meskipun bukan "proyek" Negara. Pers 
bahkan menjadi pengontrol dan pemberi koreksi kritis terhadap SDM atau alumni institusi pendidikan (Masduki, 2004:131).

\section{Perbedaan Media Penyiaran dengan Media Cetak}

Berikut ini akan dijelaskan perbedaan antara media penyiaran dengan media cetak dari proses produksi, pengolahan pesan, dan penyampaian pesan/ pendistribusian (Niryawan, 2007:64):

\begin{tabular}{|c|c|c|c|}
\hline No. & $\begin{array}{c}\text { Proses Produksi } \\
\text { Media }\end{array}$ & Cetak & Penyiaran \\
\hline 1 & $\begin{array}{l}\text { Pengumpulan } \\
\text { pesan }\end{array}$ & $\begin{array}{l}\text { a. } \text { Mencatat } \\
\text { b. Merekam gambar } \\
\text { statis (foto) }\end{array}$ & $\begin{array}{l}\text { a. Sebagaimana media } \\
\text { cetak } \\
\text { b. Menyesuaikan karakter } \\
\text { media penyiaran yaitu } \\
\text { pesan berupa suara } \\
\text { untuk media dengar } \\
\text { (radio) dan pesan } \\
\text { berupa suara dan } \\
\text { gambar untuk media } \\
\text { pandang dengar (televisi }\end{array}$ \\
\hline 2 & $\begin{array}{l}\text { Pengolahan } \\
\text { pesan }\end{array}$ & $\begin{array}{l}\text { a. Tidak akan mengolah } \\
\text { pesan yang berupa } \\
\text { pesan suara atau } \\
\text { pesan suara dan } \\
\text { gambar (bergerak) } \\
\text { b. Mengolah pesan yang } \\
\text { bisa dicetak diatas } \\
\text { kertas }\end{array}$ & $\begin{array}{l}\text { a. Mengolah suara atau } \\
\text { suara dan gambar } \\
\text { b. Peralatan yang } \\
\text { digunakan media } \\
\text { penyiaran radio berbeda } \\
\text { dengan peralatan media } \\
\text { penyiaran televisi dan } \\
\text { tentu saja berbeda } \\
\text { dengan media cetak }\end{array}$ \\
\hline 3 & $\begin{array}{l}\text { Penyampaian } \\
\text { pesan atau } \\
\text { pendistribusian }\end{array}$ & $\begin{array}{l}\text { a. Penyampaian pesan } \\
\text { dengan mencetak } \\
\text { pesan-pesannya } \\
\text { diatas kertas. }\end{array}$ & $\begin{array}{llr}\text { a. } & \text { Penyampaian } & \text { pesan } \\
\text { melalui teknologi } & \text { telekomunikasi } \\
\text { teleaik } \\
\text { berupa suara } & \text { (audio) }\end{array}$ \\
\hline
\end{tabular}




\begin{tabular}{|l|l|l|}
\hline & b. Didistribusikan & \multicolumn{1}{c|}{$\begin{array}{l}\text { maupun suara dan } \\
\text { dengan menggunakan } \\
\text { gambar (audio/visual) } \\
\text { jalur transportasi lalu } \\
\text { lintas. }\end{array}$} \\
& $\begin{array}{l}\text { b. Didistribusikan melalui } \\
\text { gelombang frekuensi } \\
\text { radio }\end{array}$ \\
\hline
\end{tabular}

\section{Media dan Berita Dilihat dari Paradigma Pluralis dan Kritis}

Paradigma pluralis percaya bahwa wartawan dan media adalah entitas yang otonom, dan berita yang dihasilkan haruslah menggambarkan realitas yang terjadi di lapangan. Sementara paradigma kritis mempertanyakan posisi wartawan dan media dalam keseluruhan struktur sosial dan kekuatan sosial yang ada dalam masyarakat. Pada akhirnya posisi tersebut mempengaruhi berita, bukan pencerminan dari realitas sesungguhnya. Perbedaan tersebut dapat digambarkan selengkapanya sebagai berikut (Eriyanto, 2009: 32):

\begin{tabular}{|l|l|l|}
\hline \multicolumn{1}{|c|}{ Pandangan Pluralis } & \multicolumn{1}{|c|}{ Pandangan Kritis } \\
\hline $\begin{array}{l}\text { Fda fakta yang real yang diatur oleh } \\
\text { kaidah-kaidah tertentu yang berlaku } \\
\text { universal }\end{array}$ & $\begin{array}{l}\text { Fakta merupakan hasil dari proses } \\
\text { pertarungan antara kekuatan ekonomi, } \\
\text { politik, dan sosial yang ada dalam } \\
\text { masyarakat }\end{array}$ \\
\hline $\begin{array}{l}\text { Berita adalah cermin dan refleksi } \\
\text { dari kenyataan. Oleh karena itu, } \\
\text { berita haruslah sama dan sebangun } \\
\text { dengan fakta yang hendak diliput }\end{array}$ & yerita tidak mungkin merupakan cermin \\
dan refleksi dari kenyataan, karena berita \\
kepentingan kekuatan dominan
\end{tabular}




\begin{tabular}{|c|c|}
\hline $\begin{array}{l}\text { Media menggambarkan diskusi apa } \\
\text { yang ada dalam masyarakat }\end{array}$ & $\begin{array}{l}\text { Media hanya dimanfaatkan dan menjadi } \\
\text { alat kelompok dominan }\end{array}$ \\
\hline \multicolumn{2}{|c|}{ Posisi wartawan } \\
\hline $\begin{array}{l}\text { Nilai dan ideology wartawan berada } \\
\text { di luar proses peliputan berita }\end{array}$ & $\begin{array}{l}\text { Nilai dan ideology wartawan tidak dapat } \\
\text { dipisahkan dari proses peliputan dan } \\
\text { pelaporan suatu peristiwa }\end{array}$ \\
\hline Wartawan berperan sebagai pelapor & $\begin{array}{l}\text { Wartawan berperan sebagai partisipan } \\
\text { dari kelompokyang ada dalam masyarakat }\end{array}$ \\
\hline $\begin{array}{l}\text { Tujuan peliputan dan penulisan } \\
\text { berita: eksplanasi dan menjelaskan } \\
\text { apa adanya memburukkan } \\
\text { kelompok }\end{array}$ & $\begin{array}{l}\text { Tujuan peliputan dan penulisan berita: } \\
\text { pemihakan kelompok sendiri dan atau } \\
\text { pihak lain }\end{array}$ \\
\hline Penjaga gerbang (gatekeeping) & Sensor diri \\
\hline Landasan etis & Landasan ideologis \\
\hline $\begin{array}{l}\text { Profesionalisme sebagai } \\
\text { keuntungan }\end{array}$ & Profesionalisme sebagai control \\
\hline $\begin{array}{l}\text { Wartawan sebagai bagian dari tim } \\
\text { untuk mencari kebenaran }\end{array}$ & $\begin{array}{l}\text { Sebagai pekerja yang mempunyai posisi } \\
\text { berbeda dalam kelas sosial }\end{array}$ \\
\hline \multicolumn{2}{|c|}{ Hasil liputan } \\
\hline $\begin{array}{l}\text { Liputan dua sisi, dua pihak dan } \\
\text { kredibel }\end{array}$ & $\begin{array}{l}\text { Mencerminkan ideology wartawan dan } \\
\text { kepentingan sosial, ekonomi, atau politik } \\
\text { tertentu }\end{array}$ \\
\hline $\begin{array}{l}\text { Objektif, menyingkirkan opini dan } \\
\text { pandangan subjektif dari } \\
\text { pemberitaan }\end{array}$ & $\begin{array}{l}\text { Tidak objektif, karena wartawan adalah } \\
\text { bagian dari kelompok/ struktur sosial } \\
\text { tertentu yang lebih besar }\end{array}$ \\
\hline $\begin{array}{l}\text { Memakai bahasa yang tidak } \\
\text { menimbulkan penafsiaran } \\
\text { beraneka }\end{array}$ & $\begin{array}{l}\text { Bahasa menunjukkan bagaimana } \\
\text { kelompok sendiri diunggulkan dan } \\
\text { memarjinalkan kelompok lain }\end{array}$ \\
\hline
\end{tabular}

\section{Kebijakan Pendidikan}

Menurut Anderson yang dikutip oleh arif rohman, kebijakan (policy) diartikan sebagai suatu arah tindakan yang bertujuan, yang dilaksanakan oleh pelaku kebijakan didalam mengatasi suatu masalah atau urusan-urusan yang bersangkutan (Rohman, 
2010:2). Dalam pengertian lain, dari rumusan yang lebih lengkap yaitu dari perserikatan bangsa-bangsa (PBB), bahwa kebijakan adalah sebagai pedoman untuk bertindak, pedoman tersebut bisa yang berwujud amat sederhana atau kompleks, bersifat umum atau khusus, luas atau sempit, kabur atau jelas, longgar atau terperinci, kualitatif atau kuantitatif, publik atau privat. Dalam hal ini kebijakan berupa suatu deklarasi mengenai suatu dasar pedoman bertindak, suatu arah tindakan tertentu, suatu program mengenai aktivitas-aktivitas tertentu atau suatu rencana (Wahab, 1997:2). Menurut analisa saya, kebijakan adalah suatu program yang berisi solusi berupa arah tindakan didalam mengatasi masalah yang dideklarasikan dan dilaksanakan oleh pelaku kebijakan tersebut. Sedang pendidikan menurut drijarkara SJ, pendidikan adalah memanusiakan manusia muda secara manusiawi. Jadi pendidikan tersebut dilakukan oleh manusia (dewasa) dengan upaya-upaya yang sungguh-sungguh serta strategi dan siasat yang tepat demi keberhasilan pendidikan tersebut (Gunawan, 1995:1).

Sedang definisi tentang Kebijakan pendidikan yaitu kebijakan pendidikan merupakan keseluruhan proses dan hasil perumusan langkah-langkah strategis pendidikan yang dijabarkan dari visi dan misi pendidiakn dalam rangka untuk mewujudkan tercapainya tujuan pendidikan dalam suatu masyarakat untuk suatu kurun waktu tertentu (Nugroho, 2009:140). Kebijakan pendidikan yang ditujukan untuk mencapai tujuan pembangunan Negara-bangsa dibidang pendidikan, sala satu bagian dari tujuan pembangunan Negara bangsa secara keseluruhan (Nugroho, 2009:268). Sehingga wujud dari kebijakan pendidikan itu berupa undang-undang pendidikan, instruksi presiden, peraturan pemerintah, keputusan pengadilan, peraturan menteri, dan sebagainya yang menyangkut pendidikan.

\section{Proses Politik dan Perumusan Kebijakan}

Masalah pendidikan adalah salah satu masalh yang bersifat universal. Semua manusia tanpa terkecuali sangat berkepentingan terhadap pendidikan. Bagi anak dan remaja, pendidikan merupakan suatu hak yang harus diterima baik melalui sekolah maupun luar sekolah. Dengan demikian, masalah-masalah kehidupan yang menyangkut dunia pendidikan merupakan masalah yang bersifat publik.

Ada tiga proses politik sebelum kebijakan dirumuskan:

1. Proses akumulasi aspirasi: Pada tahap ini tuntutan dan aspirasi banyak bermunculan di masyarakat lewat isu-isu serta diskursus publik yang 
diintrodusir oleh anggota-anggota masyarakat yang tergabung dalam aneka macam kelompok kepentingan.

2. Proses artikulasi: Pada tahap ini semua tuntutan yang diperjuangkan oleh masing-masing pemiliknya atau perwakilannya untuk bisa diakomodasikan dalam rumusan kebijakan.

3. Proses akomodasi: Pada proses ini, semua tuntutan tidak bisa diakomodasikan. Hanya beberapa aspirasi dan tuntutan dari kelompok tertentu yang bisa terakomodasi di dalamnya (Rohman, 2009:93).

\section{Pengaruh Media Massa dalam Kebijakan Pendidikan}

Media membentuk dan mempengaruhi opini publik yang menjadi sangat penting pada waktu penentuan nasib pendidikan dan peserta didik dalam perjuangan menghadapi pemerintahan yang berkuasa. Fungsi normatif media berlipat ganda: melaporkan fakta dan memberikn informasi, mendidik publik, memberi komentar menyampaikan, dan membentuk opini, lebih jauh lagi, media mengkritik, mengatur dan mengontrol pemerintah, politisi dan militer serta pegawai negeri termasuk pendidik yang otoriter (Masduki, 2004: 127). Dengan fungsi ini berarti media juga berpengaruh dalam kebijakan pendidikan, sebab campur tangan atau pengaruh pemerintah/ penguasa terhadap pendidikan ini cukup besar dengan segala kebijakan yang ditempuh demi suksesnya pendidikan seluruh warga Negara (Gunawan, 1995: 1).

Media memiliki peran besar dalam menentukan kebijakan politik sebuah negara, baik itu domestik maupun luar negeri. Media, dalam hal ini juga opini publik, memberikan pengaruhnya bagi perumusan foreign policy (FP). Hal ini dikarenakan media merupakan alat untuk mengekspresikan interpretasi dan ekspektasi dari entitas nonpemerintah dan juga alat untuk mengekspresikan dan menyebarkan suatu kebijakan yang diputuskan oleh pemerintah (Chanan, dalam Conflict and Communication Online, Vol. 2, No. 1, 2002: 2).

Secara sederhana ada empat model untuk menjelaskan fungsi media massa dalam kebijakan pendidikan:

1. Model jendela: model ini mengasumsikan perilaku para pelaku pendidikan sejak lapis bawah hingga lapis elit mempengaruhi media, menjadi pilihan agenda media. 
2. Model aktor: model ini mengimplikasikan bahwa media itu sendiri yang menentukan opini publik atas dunia pendidikan sampai pada tingkat tertentu dan karena itu ia mempengaruhi agenda politik.

3. Model kolektif: model ini mengatakan bahwa publik itu sendiri menyerap problem dari dunia nyata pendidikan lalu menentukan opininya. Opini itu pada gilirannya dipengaruhi opini pendidik yang telah dipublikasi media.

4. Model biotope: model ini mengasumsikan bahwa dalam dunia nyata segala sesuatu saling bergantung. Model ini dapat dilihat sebagai penggabungan dari ketiga model diatas (Masduki, 2004:128).

Isu strategis dalam kepartaian yaitu bagaimana menyampaikan pesan-pesan partai, dalam hal ini konsep-konsep, metode-metode, tujuan-tujuan, dll, kepada semua anggota masyarakat. Media modern dengan segala kemampuannya menjadi pilihan favorit yang harus digunakan oleh partai untuk memenangkan persaingan, tanpa memanfaatkan media mustahil bagi partai untuk dapat bertahan di dunia politik. Pemanfaatan media modern berkembang seiring dengan berkembangnya kebutuhan partai. Media pada akhirnya juga digunakan sebagai alat untuk propaganda partai, alat untuk memojokkan lawan, dan alat untuk menggiring opini publik. Pemanfaatan media lebih lanjut ini menimbulkan perang informasi yang bila dikontrol dengan baik akan menghadirkan dinamika politik yang sehat akan tetapi bila gagal akan menimbulkan chaos di dalam masyarakat.

Sesuai dengan pemaparan diatas, menurut penulis pengaruh media terhadap kebijakan pendidikan ada yang bersifat positif maupun negatif, yang dapat dilihat pada berikut ini:

1. Sebagai ruang publik untuk mencari informasi tentang sebuah partai

2. Sebagai ruang publik untuk menyampaikan pendapat, ide, saran, kritik, dan lain sebagainya yang berkaitan dengan politik

3. Sebagai ruang publik untuk berdebat dan mempertajam ide di bidang politik.

4. Sebagai ruang publik untuk propaganda partai termasuk program-program dan kebijakan-kebijakan partai.

5. Sebagai ruang publik untuk mendeskreditkan kelompok lain (dalam [FAKMEDSOSPOL] Pengaruh Media Terhadap Perpolitikan http//EREPUBLIKA the new word.com. 


\section{SIMPULAN}

Berdasarkan uraian singkat diatas, maka dapat disimpulkan: media massa adalah suatu lembaga netral yang berhubungan dengan orang banyak atau lembaga yang netral bagi semua kalangan atau masyarakat banyak. Media massa mempunyai fungsi informasi, fungsi agenda, fungsi penghubung orang, fungsi pendidikan, fungsi membujuk, dan fungsi menghibur. Jika lembaga pendidikan berperan menciptakan SDM yang berkualitas, maka menurut UU no. 40 tahun 1999, pers memiliki fungsi serupa meskipun bukan "proyek" Negara. Pers bahkan menjadi pengontrol dan pemberi koreksi kritis terhadap SDM atau alumni institusi pendidikan.

kebijakan (policy) diartikan sebagai suatu arah tindakan yang bertujuan, yang dilaksanakan oleh pelaku kebijakan didalam mengatasi suatu masalah atau urusanurusan yang bersangkutan. Maka pengaruh media massa dalam kebijakan dapat bersifat positif maupun negatif, seperti : Sebagai ruang publik untuk mencari informasi tentang sebuah partai, Sebagai ruang publik untuk menyampaikan pendapat,ide,saran,kritik, dan lain sebagainya yang berkaitan dengan politik, Sebagai ruang publik untuk berdebat dan mempertajam ide di bidang politik, Sebagai ruang publik untuk propaganda partai termasuk program-program dan kebijakan-kebijakan partai dan Sebagai ruang publik untuk mendeskreditkan kelompok lain.

\section{DAFTAR PUSTAKA}

Abdul Wahab. 1997. Analisis Kebijakan: Dari Formulasi Ke Implementasi Kebijakan Negara. Jakarta: Bumi Aksara.

Arif Rohman. 2010. Educational Policy. Yogyakarta: Pustaka Pelajar.

Ary H. Gunawan. 1995. Kebijakan-Kebijakan Pendidikan. Jakarta: Rineka Cipta

Eriyanto. 2009. Analisis Wacana: Pengantar Analisis Teks Media. Cet VII Yogyakarta: LKis.

Hari Niryawan. 2007. Dasar-Dasar Hukum Media. Yogyakarta: Pustaka Pelajar.

H.A.R. Tilaar Dan Riant Nugroho. 2009. Kebijakan Pendidikan: Pengantar Untuk Memahami Kebijakan Pendidikan Dan Kebijakan Pendidikan Sebagai Kebijakan Publik. Yogyakarta: Pustaka Pelajar. Cet II

Masduki. 2004. Kebebasan Pers Dan Kode Etik Jurnalistik. Yogyakarta: UII Press 
68 | Toha Makhshun \& Khalilurrahman

Naveh, Chanan. (2002). "The Role of the Media in Foreign Policy Decision-Making: A Theoretical Framework". Dalam Conflict and Communication Online, Vol. 2, No. 1, hal. 2

Totok Djuroto Hari Niryawan. 2004. Manajemen Penerbitan Pers. Cet III. Bandung: Remaja Rosdakarya

[FAKMEDSOSPOL] Pengaruh Media terhadap Perpolitikan. http//EREPUBLIKA the new word.com pada hari sabtu tgl. 15 Juni 2013 